\title{
FAKTOR-FAKTOR YANG MEMPENGARUHI PENDAPATAN PEDAGANG DI PASAR CANDIKUNING BATURITI KABUPATEN TABANAN
}

\author{
I WAYAN MULA SARJANA
}

\author{
Fakultas Ekonomi dan Bisnis Universitas Tabanan
}

e-mail : mulasarjana46@gmail.com

\begin{abstract}
ABSTRAK
Penelitian ini bertujuan untuk mengetahui pengaruh secara simultan maupun parsial modal usaha $\left(\mathrm{X}_{1}\right)$, jam kerja $\left(\mathrm{X}_{2}\right)$ dan lama usaha $\left(\mathrm{X}_{3}\right)$, terhadap pendapatan pedagang di Pasar Candikuning Baturiti Kabupaten Tabanan (Y). Data primer diambil dengan kusioner terhadap sampel sejumlah 47 pedagang di Pasar Candikuning. Sampel diambil dengan teknik probability sampling dari berbagai blok. Data dianalisis menggunakan regresi linear berganda. Hasil penelitian menunjukkan modal usaha, jam kerja dan lama usaha secara simultan berpengaruh nyata terhadap pendapatan pedagang di Pasar Candikuning Baturiti Kabupaten Tabanan. Modal usaha dan jam kerja secara parsial berpengaruh positif dan nyata terhadap pendapatan pedagang di Pasar Candikuning Baturiti Kabupaten Tabanan. Sedangkan lama usaha tidak berpengaruh terhadap pendapatan pedagang di Pasar Candikuning Baturiti Kabupaten Tabanan.
\end{abstract}

Kata kunci : modal usaha, jam kerja, lama usaha dan pendapatan.

\section{ABSTRACT}

This study aims to determine the effect simultaneously or partially of venture capital (X1), working hours (X2), and length of business (X3), on the income of traders in Candikuning Market, Baturiti, Tabanan Regency (Y). Primary data is taken by questionnaire from a sample of 47 traders at Candikuning Market. Samples are taken using probability sampling techniques from various blocks. Data are analyzed using multiple linear regression. The results showed that working capital, working hours, and length of business simultaneously had a significant effect on the income of traders in Candikuning Market, Baturiti, Tabanan Regency. Working capital and working hours partially have a positive and significant effect on the income of traders in the Candikuning Baturiti Market, Tabanan Regency. Meanwhile, the length of business does not affect the income of traders in Candikuning Market, Baturiti, Tabanan Regency.

Keywords: working capital, working hours, length of business, and income.

\section{PENDAHULUAN}

Perkembangan perekonomian pada saat ini bisa dilihat dari adanya pembangunan pusat perdagangan yang makin meningkat di Indonesia. Adanya pusat perdagangan merupakan salah satu indikator paling berpengaruh nyata dalam kegiatan ekonomi masyarakat di suatu wilayah. Bentuk fisik dari pusat perdagangan dibagi menjadi dua jenis yaitu pasar tradisional dan pasar modern. Dilihat dari sisi kepentingan ekonominya, semakin meningkat jumlah pusat perdagangan, baik yang tradisional maupun modern mendorong terwujudnya peluang kerja bagi masyarakat luas. Mulai dari jasa tenaga satuan pengamanan, penjaga toko, pengantar barang, cleaning service, hingga jasa transportasi. Artinya, kehadiran adanya pusat perdagangan ini ikut berkontribusi dalam mengentaskan masalah pengangguran dan kemiskinan. Dari sisi sosial, keberadaan pasar modern dapat mengancam para pedagang pasar tradisional yang merupakan golongan ekonomi menengah ke bawah.

Sektor informal sebaiknya mendapatkan dukungan dan perhatian dari pemerintah karena keberadaan sektor informal dapat menyerap banyak tenaga kerja sehingga berperan dalam membentuk perekonomian yang terbuka dan fleksibel. Sektor informal juga berkaitan dengan jalur distribusi barang dan jasa di tingkat bawah sehingga dapat lebih memeratakan perekomomian pada masyarakat menengah kebawah yang menjadi permasalahan di negara berkembang. Dalam hubungannya dengan perekonomian daerah sektor informal 
memiliki suatu keterkaitan yang tinggi dengan sektor perdagangan. Oleh sebab itu, pengembangan sektor informal merupakan suatu cara yang cukup baik untuk dapat mengatasi permasalahan ketimpangan pendapatan dan pertumbuhan ekonomi antar wilayah di suatu daerah (Tumbunan, 1996).

Meningkatkan dan mempercepat pertumbuhan ekonomi daerah yang lebih tinggi dilaksanakan dengan memberdayakan pelaku dan potensi ekonomi daerah dalam mewujudkan pertumbuhan ekonomi yang lebih tinggi serta pemerataan yang lebih adil yang akan diikuti oleh kesejahteraan masyarakat yang lebih baik. Program pembangunan yang dijalankan oleh pemerintah daerah salah satunya adalah menggalakkan sektor industri, terutama industri kecil dan menengah sebagai wadah usaha bagi sebagian masyarakat yang mampu tumbuh dan berkembang secara mandiri dengan memberikan andil besar serta menduduki peran yang strategis dalam pembangunan ekonomi di Provinsi Bali, terutama dari potensinya yang banyak menyerap tenaga kerja dan banyaknya jumlah usaha yang tersedia (Erawan, 2003).

Sangat mudah menemukan minimarket, supermarket bahkan hipermarket di perkotaan maupun pedesaan. Sudah tidak bisa dipungkiri lagi bahwa keberadaan pasar modern saat ini sudah menjadi tuntutan dan konsekuensi dari gaya hidup modern yang berkembang di masyarakat. Pasar tradisional juga masih memiliki beberapa kelebihan yang tidak dimiliki pasar modern. Diantaranya adalah masih adanya kontak sosial saat tawar menawar antar pedagang dan pembeli. Pasar tradisional juga menggambarkan denyut nadi perekonomian rakyat kebanyakan (Martini dan Widyani, 2016). Di Provinsi Bali sendiri, melemahnya kebanggaan masyarakat terhadap hal-hal yang berkaitan tradisional berbasis kearifan lokal sudah mulai tampak dengan terjadinya pergeseran trend berbelanja. Diantara berbagai segmen, dari pasar tradisional yang dikelola secara konvensional ke pasar modern yang dikelola secara lebih profesional (Rahyuda, dkk. 2012, dalam Martini, 2016).

Adanya daya tarik pasar tardisional yang khas sebagai bagian dari obyek wisata yang didukung budaya lokal, sesungguhnya dapat dijadikan sebagai peluang yang dapat dikembangkan sepanjang mampu mensinergikan semua potensi yang pada gilirannya dapat meningkatkan kesejahteraan masyarakat. Pengembangan pasar tradisional di Provinsi Bali secara lebih profesional dengan tidak meninggalkan kearifan lokal, sesungguhnya mampu menstrategiskan posisinya karena dapat menciptakan lapangan usaha dan lapangan kerja bagi sebagian masyarakat menengah kebawah dan juga melibatkan hajat hidup masyarakat yang lebih banyak (Martini dan Widyani, 2016).

Pengembangan sektor industri merupakan upaya yang tepat untuk meningkatkan taraf hidup masyarakat mengingat usaha ini sangat beraneka ragam dan dapat disesuaikan dengan kondisi sumber daya alam serta sumber daya manusia yang tersedia. Peningkatan pertumbuhan ekonomi diharapkan agar lebih berkembang dan merata, sehingga hasil-hasil pembangunan tersebut tidak hanya dinikmati oleh sebagian penduduk saja melainkan seluruh penduduknya.

Kabupaten Tabanan merupakan salah satu kabupaten yang ada di Provinsi Bali, yang merupakan salah satu tempat destinasi wisata utama para wisatawan mancanegara, masih mempertahankan nilai-nilai kebudayaan tradisonal masyarakat lokal. Hal ini terbukti dari masih dapat dijumpainya pasar tradisional di beberapa tempat di wilayah Kabupaten Tabanan yang di kelola oleh perusahaan Daerah Pasar Kabupaten Tabanan. Pasar tradisional sebagai basis ekonomi rakyat memiliki potensi besar untuk menyediakan lapangan pekerjaan, menyediakan pilihan kesempatan usaha sehingga mampu menggerakkan roda perekonomian rakyat.

Pasar tradisional tetap konsisten melayani dan menyediakan kebutuhan pokok masyarakat dalam keadaan ekonomi yang selalu mengalami fluktuasi. Hal tersebut diterapkan pula pada pasar tradisional yang didirikan dan dikelola oleh Perusahaan Daerah Pasar Kabupaten Tabanan yang memiliki tujuan untuk turut serta melaksanakan pembangunan daerah (khususnya) dan pembangunan ekonomi nasional (umumnya) serta mengusahakan ketertiban dan kelancaran distribusi bahan-bahan pokok bagi masyarakat dan membantu pemerintah dalam menyediakan lapangan pekerjaan.

Munculnya investor-investor yang membangun pusat perbelanjaan modern berupa minimarket, supermarket, department store, hypermarket dan lain - lain tentunya menjadi pesaing bagi pedagang pasar rakyat. Pemerintah Kabupaten Tabanan melalui Dinas Pasar Kabupaten Tabanan terus berupaya melakukan perbaikan pengelolaan pasar rakyat dengan penataan ulang pasar rakyat salah satunya yaitu melakukan perbaikan Pasar Baturiti tahun 2004, dalam rangka peningkatan daya saing pasar rakyat di Kabupaten Tabanan khusunya Pasar Candikuning, Baturiti Tabanan, sehingga para pedagang lebih leluasa dalam melakukan transaksi jual beli.

Jumlah kios yang ada di Pasar Candikuning, saat ini adalah 178 unit. Berikut ini adalah tabel jumlah pedagang di Pasar Candikuning Baturiti Kabupaten Tabanan tahun 2019. 
Tabel 1. Jenis dan Jumlah Pedagang di Pasar Candikuning Baturiti Kabupaten Tabanan Tahun 2019

\begin{tabular}{clcc}
\hline No & Jenis Barang Dagangan & Jumlah Pedagang (Orang) & Persentase (\%) \\
\hline 1 & Sayur-sayuran & 35 & 19.66 \\
2 & Pakaian & 48 & 26.97 \\
3 & Buah-buahan & 50 & 28.09 \\
4 & Souvenir & 15 & 8.43 \\
5 & Makanan dan minuman & 12 & 6.74 \\
6 & Oleh-oleh & 8 & 4.49 \\
7 & sembako & 6 & 3.37 \\
8 & Counter & 3 & 1.69 \\
9 & Bakso & 1 & 0.56 \\
\hline & Jumlah & $\mathbf{1 7 8}$ & $\mathbf{1 0 0}$ \\
\hline
\end{tabular}

Sumber : Kepala Pasar Candikuning, 2020

Berdasarkan Tabel 1 jenis barang dagangan yang paling banyak adalah pedagang buah-buahan berjumlah 50 pedagang atau 28,09 persen dan yang paling sedikit adalah pedagang bakso yang berjumlah 1 pedagang atau 0,56 persen.

Pasar Candikuning Baturiti Kabupaten Tabanan dipilih sebagai objek penelitian karena merupakan pasar yang potensial, dan juga lokasinya yang terletak sangat strategis berada di pusat keramaian yang menghubungkan beberapa desa disamping itu pula sebagai jalur pariwisata. Usaha berdagang hal yang menjadi tujuan pedagang adalah memperoleh pendapatan yang tinggi untuk memenuhi kebutuhan mereka. Menurut (Boediono, 2009), mengemukakan bahwa pendapatan adalah hasil dari penjualan faktor -faktor produksi yang dimilikinya kepada sektor produksi. Kesejahteraan seorang pedagang dapat diukur dari penghasilannya, oleh karena itu faktor-faktor yang mempengaruhi pendapatan pedagang harus diperhatikan supaya pendapatan pedagang stabil dan kesejahteraannya meningkat sehingga jual- beli di pasar tetap berjalan lancar, jumlah pedagang yang ada akan tetap bertahan dan semakin bertambah.

Penelitian ini menggunakan variabel modal, jam kerja dan lama usaha sebagai faktor yang mempengaruhi tingkat pendapatan pedagang di Pasar Candikuning Baturiti Kabupaten Tabanan. Modal merupakan harta yang dimiliki perusahaan yang dipergunakan untuk menjalankan kegiatan usaha atau membiayai operasional perusahaan tanpa mengorbankan aktiva yang lain dengan tujuan memperoleh laba yang optimal. Modal merupakan kunci dari setiap usaha. Modal dagang yang besar sangat mempengaruhi pendapatan, karena dengan modal yang besar para pedagang mempunyai kesempatan penambahan kuantitas, jenis barang yang ditawarkan pedagang kepada pembeli.

Setelah usaha dimulai, yang diperlukan suatu usaha agar dapat berjalan lancar dan berkembang adalah pengelolaan yang baik. Salah satu faktor penting dalam mengelola suatu usaha adalah menentukan jam kerja. Jam kerja adalah banyaknya lama waktu kerja dalam sehari. Satuan variabel jam kerja adalah jam per-hari. Namun belum tentu semua kios memiliki jam kerja yang sama. Jika ingin memperoleh pendapatan yang tinggi maka diperlukan jam kerja yang tinggi pula. Semakin lama jam kerja atau operasional seunit kios dan los dipasar maka akan semakin tinggi pula kesempatan untuk memperoleh pendapatan yang tinggi.

Selain itu, lama usaha juga memberikan pengaruh penting dalam pendapatan. Pedagang yang lebih lama dalam menggeluti usahanya akan memiliki pengalaman usaha yang lebih banyak sehingga akan memiliki strategi yang lebih matang dan tepat dalam mengelola dan memasarkan produknya (Damayanti, 2011). Jacobsen (1998) dalam Aswar (2011) menambahkan bahwa dengan meningkatnya pengalaman akan meningkatkan penerimaan di masa akan datang.

\section{Rumusan Masalah}

Berdasarkan latar belakang, maka peneliti akan meneliti tentang analisis faktor-faktor yang mempengaruhi pendapatan pedagang di Pasar Candikuning Baturiti Kabupaten Tabanan.

\section{Tujuan Penelitian}

Adapun tujuan dari penelitian ini adalah : 1) untuk menganalisis bagaimana pengaruh modal usaha, jam kerja dan lama usaha pedagang secara simultan terhadap pendapatan pedagang di Pasar Candikuning, 2) untuk menganalisis bagaimana pengaruh modal usaha, jam kerja dan lama usaha secara parsial terhadap pendapatan pedagang di Pasar Candikuning. 


\section{METODE PENELITIAN}

Penelitian ini berbentuk kuantitatif dan bersifat asosiatif yaitu untuk meneliti analisis faktor-faktor yang mempengaruhi pendapatan pedagang di Pasar Candikuning. Alasan pemilihan lokasi ini sebagai lokasi penelitian karena Pasar Candikuning merupakan salah satu pasar yang potensial dan juga lokasinya yang terletak sangat strategis sebagai jalur pariwisata di Kabupaten Tabanan, memiliki permasalahan yaitu karena terdapat perbedaan pendapatan antara pedagang yang diduga dipengaruhi oleh modal, jam kerja dan lama usaha. maka perlu dilakukan penelitian terhadap kecenderungan perbedaan pendapatan pedagang di Pasar Candikuning. Pasar Candikuning merupakan salah satu pusat kegiatan wisata belanja yang dapat dijadikan sebagai parameter tingkat kunjungan wisatawan di Kabupaten Tabanan, maka diperlukan suatu penelitian untuk menciptakan kenyamanan bagi pengunjung Pasar Candikuning. Pasar Candikuning juga merupakan wujud perencanaan pembangunan yang berpihak kepada industri kerakyatan dan UMKM sesuai dengan startegi dan kebijakan Pemerintah Kabupaten Tabanan dalam rangka mendorong pertumbuhan ekonomi yang berkelanjutan.

Objek penelitian ini berfokus pada faktor-faktor yang mempengaruhi pendapatan pedagang di Pasar Candikuning. Variabel dependen atau variabel terikat yang digunakan pada penelitian ini adalah pendapatan pedagang. Pendapatan pedagang adalah hasil atau pendapatan yang diterima para pedagang dari kegiatan berdagang di Pasar Candikuning yang diukur dalam satuan rupiah dan dalam periode 1 (satu) bulan.

Variabel independen atau variabel bebas dalam penelitian ini adalah modal, jam kerja dan lama usaha pedagang di Pasar Candikuning. Modal usaha adalah dana yang diperlukan oleh pedagang untuk memenuhi kebutuhan operasional usahanya sehari-hari, seperti pembelian bahan baku, pembayaran upah buruh, membayar hutang dan pembayaran lainnya. Satuan modal yang digunakan adalah rupiah dan periode modal usaha yaitu 1 (satu) bulan. Jam kerja adalah jumlah waktu yang dibutuhkan pedagang untuk melakukan suatu pekerjaan atau kegiatan berdagang dari mulai persiapan sampai tutup kios. Satuan variabel jam kerja pedagang adalah satuan jam per hari. Lama usaha adalah lama waktu yang sudah dijalani pedagang dalam menjalankan usahanya dan diukur dalam satuan tahun.

Data kuantitatif dalam penelitian ini menyangkut antara lain jumlah pedagang, jumlah modal usaha, jumlah pendapatan, jam kerja dan lama usaha di Pasar Candikuning. Data kualitatif adalah data yang berupa keterangan atau uraian-uraian atas pertanyaan yang diberikan kepada responden yang dipergunakan untuk memberikan penjelasan tentang karakteristik dan data lainnya

yang sifatnya mendukung penelitian ini. Sumber data dalam penelitian ini adalah data primer dan data sekunder. Data primer dalam penelitian ini didapatkan dari hasil pengisian kuisioner dan mewawancarai terhadap responden yaitu pedagang di Pasar Candikuning serta pihak terkait seperti pengelola pasar dan pengunjung pasar. Data sekunder diperoleh dari jurnal, laporan berbagai naskah yang relevan dari dinas terkait. Data sekunder yang dikumpulkan diantaranya berupa profil Pasar Candikuning dan data lain yang berkaitan dengan penelitian ini.

Populasi adalah wilayah generalisasi yang terdiri dari objek atau subjek yang menjadi kuantitas dan karakteristik tertentu yang ditetapkan oleh peneliti untuk dipelajari dan kemudian ditarik kesimpulanya (Sugiyono,2016). Populasi dalam penelitian ini adalah seluruh pedagang Pasar Candikuning yang mempunyai tempat berjualan/kios sebanyak 178 pedagang. Jumlah sampel dalam penelitian ini ditentukan berdasarkan rumus Slovin dengan rumus sebagai berikut (Irawan dan Ayuningsasi, 2017).

$$
\begin{aligned}
& n=\frac{N}{1+N e^{2}} \\
& n=\frac{178}{1+178 \times 0,1^{2}} \\
& n=\frac{178}{1+2,78} \\
& n=47,08
\end{aligned}
$$

Berdasarkan perhitungan rumus slovin dengan e sebesar 10 persen diproleh sampel 47,08 dibulatkan menjadi 47 sampel. Jadi jumlah pedagang di Pasar Candikuning yang dijadikan sampel adalah sebanyak 47 pedagang. Karena sampel bersifat homogen maka untuk memperoleh responden diatas dilakukan dengan teknik probability sampling.

Metode pengumpulan data dalam penelitian ini menggunakan kuisoner (angket), wawancara dan studi kepustakaan. Kuesioner di bagikan kepada responden yaitu pedagang di Pasar Candikuning. Wawancara dilakukan terhadap pihak manajemen dan responden. Wawancara terhadap pedagang dilakukan pada saat peneliti melakukan studi pendahuluan untuk menemukan permasalahan yang harus diteliti. Wawancara terhadap responden dilakukan guna memperdalam jawaban dari pertanyaan yang ada dalam kuisioner jika 
diperlukan. Studi pustaka dimaksudkan untuk mengumpulkan dasar-dasar teori guna memecahkan masalah yang ada kaitannya dengan obyek penelitian dan untuk mengumpulkan data sekunder dari pihak terkait seperti pengelola pasar, dinas perdagangan, dan lain-lain.

Teknik analisis data yang digunakan dalam penelitian ini adalah analisis regresi linear berganda. Analisis ini digunakan untuk mengetahui pengaruh variabel bebas terhadap variabel terikat. Pengujian dilakukan dengan uji t (uji parsial) dan uji F (uji serempak). Adapun persamaan regresi menurut (Gujarati, 2005) adalah sebagai berikut :

$$
\mathrm{Y}=\beta_{0}+\beta_{1} \mathrm{X}_{1}+\beta_{2} \mathrm{X}_{2}+\beta_{3} \mathrm{X}_{3}+\mathrm{ei}
$$

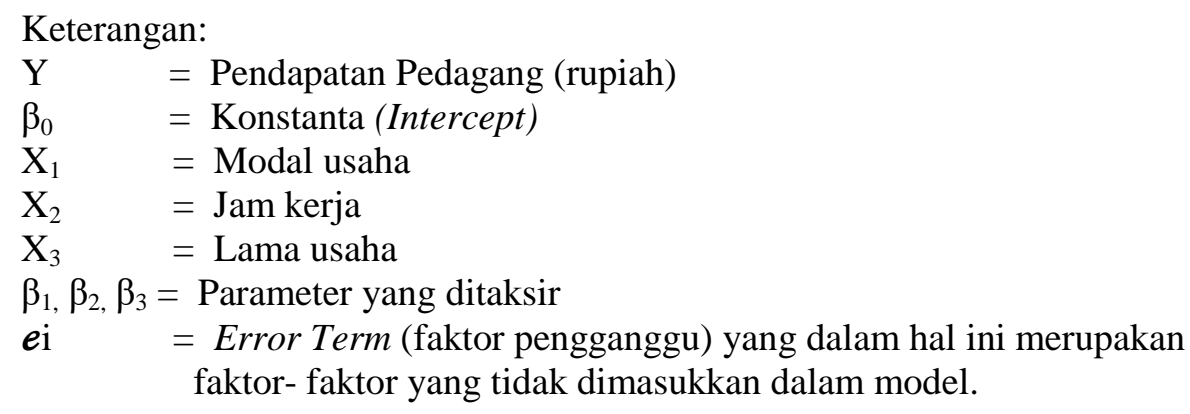

\section{HASIL DAN PEMBAHASAN}

\section{Hasil analisis regresi linear berganda}

Analisis regresi linear berganda digunakan untuk menjawab hipotesis apakah modal, jam kerja dan lama usaha secara parsial maupun simultan berpengaruh terhadap pendapatan pedagang di Pasar Candikuning, Baturiti, Kabupaten Tabanan. Adapun rangkuman dari hasil pengolahan data-data dan penjelasannya dapat kita lihat pada Tabel 2 :

Tabel 2. Hasil Perhitungan Regresi Linear Berganda Metode Full Regresssion

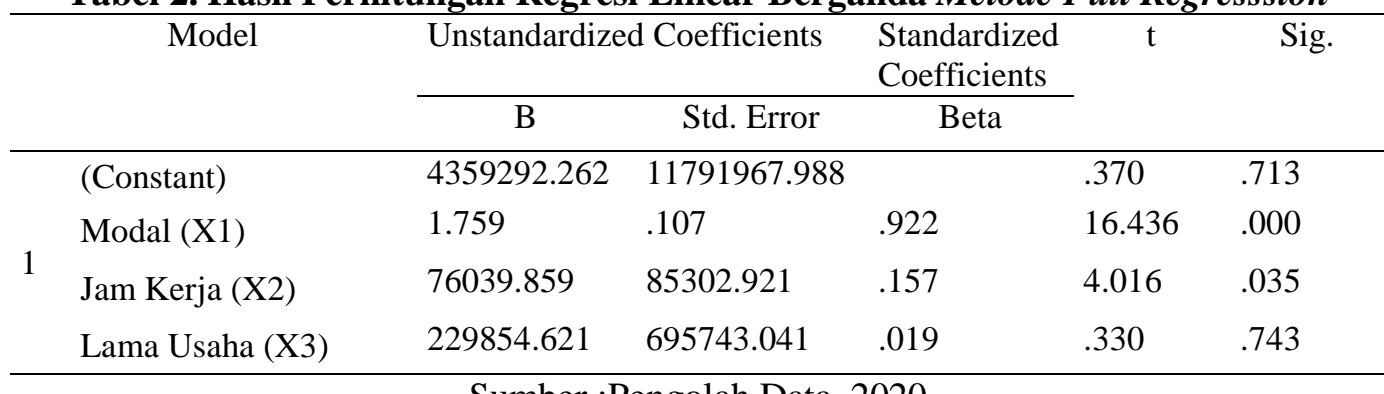

Sumber :Pengolah Data, 2020

Berdasarkan Tabel di atas, maka diperoleh persamaan model regresi linear berganda sebagai berikut :

$$
\mathrm{Y}=4.359 .292,262+1,759 \mathrm{X}_{1}+76.039,859 \mathrm{X}_{2}+229.854,621 \mathrm{X}_{3}
$$

Berdasarkan persamaan regresi linear di atas, maka dapat dijelaskan koefisien regresinya masingmasing sebagai berikut :

1. Koefisien regresi $\left(b_{1}\right)$ untuk variabel modal $\left(X_{1}\right)$, diperoleh sebesar 1,759 (bertanda positif), artinya hubungan variabel bebas dengan variabel terikat adalah searah atau setiap modal bertambah satu rupiah, maka pendapatan pedagang di Pasar Candikuning, Baturiti, Kabupaten Tabanan, akan meningkat rata-rata sebesar Rp 1,759 setiap bulan dengan asumsi variabel lainnya adalah konstan.

2. Koefisien regresi $\left(b_{2}\right)$ untuk variabel jam kerja $\left(X_{2}\right)$ diperoleh sebesar $76.039,859$ (bertanda positif), artinya hubungan variabel bebas dengan variabel terikat adalah searah atau setiap jam kerja bertambah satu jam, maka pendapatan pedagang di Pasar Candikuning, Baturiti, Kabupaten Tabanan, akan meningkat rata-rata sebesar Rp 76.039,859 setiap bulan dengan asumsi variabel lainnya adalah konstan.

3. Koefisien regresi $\left(b_{3}\right)$ untuk variabel lama usaha $\left(X_{3}\right)$ diperoleh sebesar 229.854,621 (bertanda positif), artinya hubungan variabel bebas dengan variabel terikat adalah searah atau setiap lama usaha bertambah satu tahun, maka pendapatan pedagang di Pasar Candikuning, Baturiti, Kabupaten Tabanan, akan meningkat rata-rata sebesar Rp 229.854,621 setiap bulan dengan asumsi variabel lainnya adalah konstan. 


\section{Uji hipotesis pertama (Uji-t)}

Uji hipotesis secara parsial atau uji t digunakan untuk menguji pengaruh masing-masing variabel bebas (X) terhadap variabel terikat (Y). Dengan melakukan pengujian secara parsial maka dapat diketahui signifikan tidaknya pengaruh masing-masing variabel bebas terhadap pendapatan pedagang di Pasar Candikuning, Baturiti, Kabupaten Tabanan (Y).

Pengujian dengan menggunakan uji t dilakukan dengan cara membandingkan nilai $t$ tabel dengan nilai $\mathrm{t}$ hitung atau membandingkan signifikannya pada tarap nyata $0,05(5 \%)$. Nilai $\mathrm{t}$ tabel adalah sebesar 1,681. Berdasarkan Tabel 4.7 dapat diketahui besarnya nilai thitung dan tingkat signifikannya sebagai berikut :

1. Pengaruh modal $\left(\mathrm{X}_{1}\right)$ terhadap pendapatan pedagang di Pasar Candikuning, Baturiti, Kabupaten Tabanan. Berdasarkan Tabel di atas dapat diketahui bahwa t hitung diperoleh sebesar 16,436 sedangkan $\mathrm{t}$ tabel dengan derajat 0,05 , diperoleh sebesar 1,681. Oleh karena itu, t hitung lebih besar dari t tabel $(16,436>1,681)$ dan singnifikannya sebesar 0,000 , lebih kecil dari 0,05 maka Ho ditolak Ha diterima, modal berpengaruh nyata positif terhadap pendapatan pedagang di Pasar Candikuning, Baturiti, Kabupaten Tabanan.

2. Pengaruh jam kerja $\left(\mathrm{X}_{2}\right)$ terhadap pendapatan pedagang di Pasar Candikuning, Baturiti, Kabupaten Tabanan. Berdasarkan Tabel di atas diketahui t hitung diperoleh sebesar 4,016 sedangkan $t$ tabel dengan derajat 0,05 diperoleh sebesar 1,681. Oleh karena itu thitung lebih besar dari t tabel $(4,016>1,681)$ dan signifikannya adalah 0,035 lebih kecil 0,05 maka Ho ditolak Ha diterima berarti jam kerja berpengaruh nyata positif terhadap pendapatan pedagang di Pasar Candikuning, Baturiti, Kabupaten Tabanan.

3. Pengaruh lama usaha $\left(\mathrm{X}_{3}\right)$ terhadap pendapatan pedagang di Pasar Candikuning, Baturiti, Kabupaten Tabanan. Berdasarkan Tabel di atas diketahui t hitung diperoleh sebesar 0,330 sedangkan $t$ tabel dengan derajat 0,05 diperoleh sebesar 1,681. Oleh karena itu t hitung lebih kecil dari t tabel $(0,330>1,681)$ dan signifikannya adalah 0,743 lebih besar dari 0,05 maka Ho diterima Ha ditolak berarti lama usaha tidak berpengaruh nyata positif terhadap pendapatan pedagang di Pasar Candikuning, Baturiti, Kabupaten Tabanan.

\section{Uji hipotesis kedua (Uji F)}

Uji $\mathrm{F}$ adalah alat statistik yang digunakan untuk menentukan pengaruh secara serempak atau simultan variabel-variabel bebas yaitu modal, jam kerja dan lama usaha terhadap variabel terikat yaitu pendapatan pedagang di Pasar Candikuning, Baturiti, Kabupten Tabanan. Derajat kepercayaan yang digunakan adalah 0,05. Apabila nilai F hitung lebih besar dari nilai $\mathrm{F}$ tabel, maka hipotesis alternatif, yang menyatakan bahwa semua variabel bebas secara simultan berpengaruh nyata terhadap variabel terikat. Untuk analisisnya dari output SPSS dapat dilihat dari tabel Model Summary, lebih jelasnya dapat dilihat pada Tabel 3 sebagai berikut :

Tabel 3. Hasil Perhitungan Regresi Linear Berganda Model Summary

\begin{tabular}{|c|c|c|c|c|c|c|c|c|c|c|}
\hline \multirow[t]{2}{*}{ Model } & \multirow[t]{2}{*}{$\mathrm{R}$} & \multirow{2}{*}{$\begin{array}{l}\mathrm{R} \\
\text { Square }\end{array}$} & \multirow{2}{*}{$\begin{array}{l}\text { Adjus } \\
\text { ted R } \\
\text { Squar } \\
\text { e }\end{array}$} & \multirow{2}{*}{$\begin{array}{l}\text { Std. Error of } \\
\text { the Estimate }\end{array}$} & \multicolumn{6}{|c|}{ Change Statistics } \\
\hline & & & & & $\begin{array}{l}\text { R Square } \\
\text { Change }\end{array}$ & $\begin{array}{l}\mathrm{F} \\
\text { Change }\end{array}$ & df1 & df2 & $\begin{array}{l}\text { Sig. } \\
\text { Change }\end{array}$ & $F$ \\
\hline 1 & $.931^{\mathrm{a}}$ & .867 & .858 & 4964906.51 & .867 & 93.309 & 3 & 43 & .000 & \\
\hline
\end{tabular}

Berdasarkan Tabel di atas diperoleh nilai $\mathrm{F}$ hitung sebesar 93.309 sedangkan $\mathrm{F}$ tabel dengan tarif nyata 0,05 adalah sebesar 2,82 berarti $\mathrm{F}$ hitung lebih besar dari $\mathrm{F}$ tabel $(93,309>2,82)$ dan signifikannya adalah 0,000 lebih kecil dari tarif nyata $0,05(0,000<0,05)$ maka Ho ditolak dan Ha diterima. Dengan demikian dapat dikatakan bahwa variabel-variabel bebas yaitu modal, jam kerja dan lama usaha berpengaruh nyata (signifikan) secara simultan terhadap variabel terikat yaitu pendapatan pedagang di Pasar Candikuning, Baturiri, Kabupaten Tabanan.

\section{Koefisien determinasi $\left(\mathbf{R}^{2}\right)$.}

Berdasarkan Tabel di atas besarnya pengaruh variabel-variabel bebas terhadap variabel terikat secara serempak dapat diketahui dari besarnya nilai koefisien determinasinya $\left(\mathrm{R}^{2}\right)$. PadaTabel di atas diketahui $\mathrm{R}^{2}$ adalah sebesar 0.867 berarti bahwa variabel-variabel bebas (modal, jam kerja dan lama usaha) tersebut secara bersama-sama memberikan kontribusi sebesar 86,7 persen terhadap pendapatan pedagang di Pasar Candikuning, Baturiti, Kabupaten Tabanan. Sisanya sebesar 13,3 persen, dipengaruhi oleh faktor lain yang tidak dijelaskan dalam model ini. 


\section{PENUTUP}

\section{Simpulan}

Berdasarkan hasil dan pembahasan sebelumnya, maka dapat dibuat simpulan sebagai berikut :

1. Modal berpengaruh positif dan nyata secara parsial terhadap pendapataan pedagang di Pasar Candikuning, Baturiti, Kabupaten Tabanan.

2. Jam kerja berpengaruh positif dan nyata secara parsial terhadap pendapataan pedagang di Pasar Candikuning, Baturiti, Kabupaten Tabanan.

3. Lama usaha tidak berpengaruh positif dan nyata secara parsial terhadap pendapataan pedagang di Pasar Candikuning, Baturiti, Kabupaten Tabanan.

4. Modal, jam kerja dan lama usaha secara bersama-sama atau simultan berpengaruh nyata terhadap pendapataan pedagang di Pasar Candikuning, Baturiti, Kabupaten Tabanan.

\section{Saran}

Berdasarkan hasil penelitian di atas, maka saran yang dapat diberikan sebagai berikut :

1. Berkaitan dengan modal usaha untuk para pedagang di Pasar Candikuning, Baturiti, Kabupaten Tabanan harus ada manajemen modal, sehingga usaha tersebut akan berkelanjutan.

2. Berkaitan dengan jam kerja untuk para pedagang yang memiliki jam kerja lebih sedikit dibandingkan pedagang lain harus menambah jam kerja dan memanfaatkan waktu berjualan dengan lebih bijak agar pendapatan yang diperoleh para pedagang semakin besar.

3. Berkaitan dengan lama usaha untuk para pedagang disarankan untuk selalu tekun dalam menjalankan usahanya agar dapat mengasah kemampuan profesionalnya dalam berdagang, dapat meningkatkan pengetahuan tentang selera atau perilaku konsumen, keterampilan berdagang makin bertambah, dan semakin banyak pula relasi bisnis maupun pelanggan yang berhasil dijaring.

\section{DAFTAR PUSTAKA}

Aswar. (2011). Analisis Pendapatan Pedagang Pasar Tradisional di Kota Makassar. Skripsi. Jurusan Ilmu Ekonomi FEB UNHAS. Makassar: UNHAS

Damayanti, Ifany. (2011). Analisis Faktor-Faktor Yang Mempengaruhi Pendapatan Pedagang di Pasar Gede Kota Surakarta. Skripsi. Surakarta: Universitas Sebelas Maret

Gujarati, Damodar. (2005). Ekonometrika Dasar. Jakarta: Erlangga

Irawan, Hendra dan Ayuningsasi, A.A Ketut. (2017). Analisis Variabel Yang Mempengaruhi Pendapatan Pedagang di Pasar Kreneng. E-Jurnal EP Unud, 6 (10) : 1952-1982

Sugiyono. (2016). Metode Penelitian Kombinasi (Mix Methods). Bandung: Alfabeta 